\title{
Evaluation of the Protective Efficacy of Reshaped Human Monoclonal Antibody RSHZ19 against Respiratory Syncytial Virus in Cotton Rats
}

\author{
PHILIP R. WYDE, DONNA K. MOORE, TIMOTHY HEPBURN, CAROL L. SILVERMAN, \\ TERENCE G. PORTER, MITCHELL GROSS, GERALDINE TAYLOR, SANDRA G. DEMUTH, \\ AND SUSAN B. DILLON \\ Department of Microbiology and Immunology, Baylor College of Medicine, Houston, Texas 77030 \\ [P.R.W., D.K.M.], SmithKline Beecham Pharmaceuticals, King of Prussia, Pennsylvania 19406-0939 \\ [T.H., C.L.S., T.G.P., M.G., S.G.D., S.D.], and Institute for Animal Health, Compton, \\ United Kingdom [G.T.]
}

\begin{abstract}
Reshaped human MAb RSHZ19, which is specific for the surface fusion protein of respiratory syncytial virus (RSV) is in clinical development for the prevention and treatment of RSVinduced disease in human infants. The current studies profile lung virus clearance and evaluate lung histopathology in MAbtreated, RSV-infected cotton rats, a well characterized model of $\mathrm{RSV}$ infection. The highest dose of this MAb $(10 \mathrm{mg} / \mathrm{kg})$ administered parenterally $24 \mathrm{~h}$ before infection decreased subgroup A or B RSV lung titers to below detectable levels $\left(\geq 2.3 \log _{10}\right.$ reduction), and significantly reduced lung virus titers $\left(\geq 2.0 \log _{10}\right.$ reduction) when administered $96 \mathrm{~h}$ postinfection. Prophylactic administration of $10 \mathrm{mg} / \mathrm{kg}$ RSHZ19 was significantly more protective than $1000 \mathrm{mg} / \mathrm{kg}$ conventional human immune serum globulin (HSIg), and protective serum-neutralizing titers in MAb-treated animals (1:32, which correlated with approximately $40 \mu \mathrm{g} / \mathrm{ml}$ determined by anti-idiotype ELISA) were significantly lower than those reported previously for HSIg or for convales-
\end{abstract}

cent human serum (1:200-1:400). MAb concentration in lung lavages was determined by ELISA to be approximately $1 \%$ of the serum MAb concentration, but was not detectable by neutralization assay. The degree of lung histopathology in MAb-treated cotton rats was proportional to lung virus titer, and inversely proportional to the RSHZ19 dose administered. There was no evidence of exacerbated disease in the lungs of MAb-treated animals. These studies thus support the potential clinical utility of RSHZ19 MAb in the prevention and treatment of RSVinduced disease in humans. (Pediatr Res 38: 543-550, 1995)

Abbreviations

RSV, respiratory syncytial virus

HSIg, human serum Ig

FI, fusion inhibition

TCID $_{50}$, tissue culture $50 \%$ infectious dose

F protein, fusion protein
$\mathrm{RSV}$ is a leading cause of serious lower respiratory tract infection in infants and children under $2 \mathrm{y}$ of age (1). No vaccines are currently available for prevention of RSV infections, and the only antiviral available to treat RSV disease, ribavirin, is restricted to use in high risk or severely ill infants (2). Because it is routinely administered as a continuous small particle aerosol (usually over a period of days) and is a potential teratogen, the utilization of ribavirin has been both limited and somewhat controversial (3).

A number of studies in animals (4-8) and more recently in children (9-11), indicate that HSIg selected for high neutral-

Received September 21, 1994; accepted May 11, 1995.

Correspondence and reprint requests: Philip R. Wyde, Ph.D., Department of Microbiology, Baylor College of Medicine, 1 Baylor Plaza, Houston, TX 77030.

Supported in part by National Institute of Allergy and Infectious Disease contract NO1 15099 (P.R.W.) and by the Ministry of Agriculture, Food and Fisheries, United Kingdom (G.T.). izing titers to RSV may be useful as an alternative or complementary approach to ribavirin and RSV vaccines in the prevention and treatment of these infections. However, the clinical data from a prophylaxis trial indicate that even pooled RSV immune globulin (RSV Ig) preparations selected for high anti-RSV neutralizing titers must be administered at very high doses $(750 \mathrm{mg} / \mathrm{kg})$ to achieve significant protective effects (10).

$\mathrm{MAb}$ with $\mathrm{RSV}$ neutralizing activity might be superior to pooled immune globulin preparations in terms of uniform specificity and improved potency. Numerous RSV-specific murine MAb have been described, but the potential for immunogenicity and suboptimal half-life may limit the utility of these in humans (12). The technology of antibody humanization (also referred to as reshaping or complementarity determining region grafting), attempts to address these issues by transferring the murine heavy and light chain antigen-binding hypervariable complementarity determining regions into hu- 
man variable framework regions which are expressed with human heavy and light chain constant regions to produce intact IgG molecules (13). In this way, the specificity and biologic activity characteristic of a murine $\mathrm{MAb}$ can be retained in a human IgG structure.

RSHZ19 is a reshaped human MAb $(\operatorname{IgG1,} \kappa)$ which is specific for the F protein of RSV (14) (RSHZ19 is described as HuRSV19VHFNS/VK in Ref. 14.) This MAb, which had been shown previously to protect $\mathrm{Balb} / \mathrm{c}$ mice from subgroup $\mathrm{A}$ RSV infection $(14,15)$ is currently being evaluated in human clinical trials (16). The parent murine MAb (MAb 19), which was generated by inoculating Balb/c mice intranasally with the A2 RSV strain, was shown to have potent fusion-inhibiting activity, and to bind to a panel of subgroup $A$ and $B$ isolates $(14,15)$. The current studies were performed in the cotton rat, a well established model of RSV infection, to evaluate: 1 ) the spectrum of activity of RSHZ19 versus subgroup A and B RSV strains, 2) the potency of RSHZ19 for lung virus clearance, 3) protective circulating antibody titers and direct comparison to polyclonal HSIg administered comparably, and 4) the potential for pulmonary histopathology. The data obtained indicate that potency relative to conventional HSIg is improved at least 100 -fold, and that lung virus replication and lung histopathology in subgroup A- or B-infected animals is inversely correlated with the dose of MAb administered.

\section{METHODS}

Animals. All cotton rats (Sigmodon hispidus) used in these studies were descendants of two pair of animals obtained in 1984 from the Small Animal Section of the Veterinary Research Branch, Division of Research Services, National Institutes of Health. Test animals were between 60 and $110 \mathrm{~g}$ at the start of each experiment, and of either sex. All animals were maintained in cages with barrier filters, and were fed water and food ad libitum.

Tissue culture. HEp-2 cells (ATCC CCL 23) or VERO cells (ATT CCL 81) were used to grow and test for the presence of RSV. Both cell lines were originally obtained from the American Type Culture Collection (ATCC, Bethesda, MD) and serially passaged in Eagle's minimal essential medium, supplemented with $10 \%$ FCS, $100 \mathrm{Us} / \mathrm{ml}$ penicillin, $100 \mu \mathrm{g} / \mathrm{ml}$ streptomycin sulfate, $2 \mathrm{mM}$ L-glutamine, and $0.2 \%$ sodium bicarbonate whenever they became confluent. Minimal essential medium supplemented with $2 \%$ FCS was used to maintain HEp-2 cell cultures and in all virus and antibody assays.

Viruses. RSV A2, an A subtype RSV, was obtained from the ATCC (catalog no. VR1302). RSV 18537, a B subtype RSV, and all of the clinical RSV isolates used in these studies were obtained from Tony Piedra, M.D., Department of Microbiology and Immunology, Baylor College of Medicine. The identification of the clinical isolates as subtype A or B RSV was made by Dr. Larry Anderson, Centers for Disease Control, Atlanta, GA. Stocks of these viruses were prepared by infecting monolayers of HEp-2 cells. When the infected monolayers exhibited approximately $90 \%$ syncytia formation, the cells and medium from the monolayers were collected, pooled, and clarified by centrifugation $(450 \times g)$. The resulting supernatant fluids were passed through a $0.45 \mu \mathrm{m}$ filter, portioned, and stored at $-70^{\circ} \mathrm{C}$.

$M A \boldsymbol{b}$. The production, reshaping, and characterization of reshaped human MAb, RSHZ19, have all been described in detail by Tempest et al. (14). Briefly, this MAb was constructed by grafting the complimentarity determining regions from a murine MAb (MAb19) specific for the F protein of RSV $(15,17)$, into human IgG heavy and $\kappa$ light chain-variable domain frameworks. MAb CMHZOO, which had identical human constant and variable framework regions as RSHZ19, but which was engineered to bind human cytomegalovirus (it does not bind RSV), was used as a comparative control. The cell line expressing the CMHZOO MAb was obtained from Scotgen Biopharmaceuticals, Inc., Aberdeen, Scotland. The $\mathrm{MAb}$ were purified from conditioned medium using conventional protein $\mathrm{A}$ affinity cation exchange and gel filtration chromatography procedures. The purified antibodies appeared homogeneous after SDS-PAGE and during analytical size exclusion chromatography, resolved as single peaks with apparent molecular masses of $160 \mathrm{kD}$. Endotoxin levels in all preparations were below $1 \mathrm{ng} / \mathrm{mg}$ protein.

HSIg. The HSIg preparation used in these experiments was obtained from Armour Pharmaceuticals, Phoenix, AZ (Gammar, lot S19610); this preparation (intramuscular formulation) contained $165 \mathrm{mg}$ of $\gamma$-globulin $/ \mathrm{ml}$. In microneutralization and FI antibody assays (described below) using a panel of different subtype A and B RSV viruses, the RSV-neutralizing titers of this preparation ranged from 6400 to $12,800\left(\mathrm{EC}_{50}\right.$ range $=$ $12.5-25 \mu \mathrm{g} / \mathrm{ml}$ ), whereas the FI antibody titers ranged from 1240 to $2480\left(\mathrm{EC}_{50}\right.$ range $\left.=65-130 \mu \mathrm{g} / \mathrm{ml}\right)$.

Virus quantification. Serial $0.5 \log _{10}$ dilutions of each test sample in $2 \%$ FCS-minimal essential medium were added to microtiter plates containing $3 \times 10^{3} \mathrm{HEp}-2$ cells/well and incubated at $36^{\circ} \mathrm{C}\left(5 \% \mathrm{CO}_{2}\right)$. On $\mathrm{d} 7$, the wells were scored by visual inspection (without staining) for the formation of syncytia. Calculation of endpoints were made using the method of Karber (18). The amount of virus present in each suspension was expressed either as median $\mathrm{TCID}_{50} / \mathrm{ml}$, or if lung suspensions were involved, geometric mean virus titers $\left(\log _{10}\right.$ $\mathrm{TCID}_{50} / \mathrm{g}$ of lung). The minimum detectable virus concentration was $1.3 \log _{10} / \mathrm{g}$ of lung.

Antibody assays. Assays for detecting and quantifying virusspecific neutralizing antibodies in sera, lung lavage fluids, or MAb suspensions were performed in duplicate in HEp-2 tissue cells in microtiter plates as described in detail elsewhere (19). Approximately $100 \mathrm{TCID}_{50}$ virus was used, unless otherwise noted. Antibody levels in MAb preparations were expressed as the IgG concentration that completely inhibited virus in onehalf the replicate wells $\left(\mathrm{EC}_{50}\right)$. The minimum detectable neutralizing titer in serum was $1 \log _{2}$. Mean serum neutralization titers were derived from individual animals or from pooled sera from each treatment group in each experiment (three to four animals/group), depending on quantity of sera obtained per animal.

FI assays were performed in quadruplicate as described by Mufson et al. (20). The FI titer was expressed as the $\log _{2}$ of the reciprocal of the highest dilution which completely inhibited syncytia formation. 
An anti-idiotypic ELISA was used to specifically measure serum and lung lavage concentrations of RSHZ19. The RSHZ19-specific anti-idiotypic MAb used as the capture antibody in this assay was generated by immunizing calves with the parent murine MAb (MAb19), and will be described in detail elsewhere (Taylor G., in preparation). Bound RSHZ19 was quantitated with peroxidase labeled anti-human IgG or with biotinylated anti-idiotypic MAb. To compare circulating concentrations of human IgG in cotton rats treated with RSHZ19 MAb or with HSIg, goat anti-human IgG was used as the capture antibody, and bound $\operatorname{IgG}$ was detected with peroxidase-labeled sheep anti-human IgG.

Experimental designs. Test antibody preparations were administered intraperitoneally or intramuscularly as noted in the text. Virus was always administered intranasally. For prophylactic studies, the cotton rats were anesthetized with Metofane, bled, and inoculated with control MAb (CMHZOO) or test MAb (RSHZ19) $24 \mathrm{~h}$ before challenge with approximately 100 $\mathrm{TCID}_{50}$ of subgroup A (strain A2) or B (strain 18537) RSV. The animals were killed on $\mathrm{d} 4$ postinfection (at which time maximal RSV replication usually occurs), and serum and lung lavages ( $3 \mathrm{ml}$ ) were collected as described previously (20) for antibody and virus titrations. In some instances, nasal washes (21), as well as lavage fluids, were collected for virus titrations. For therapeutic studies, animals were treated with test or control MAb on d 4 postinfection with RSV strain A2 or 18537 and killed $24 \mathrm{~h}$ later. In each experiment, three to four cotton rats per dose group were included.

In some studies, additional animals were included for histologic studies on $\mathrm{d} 7$ postinfection when maximum virusinduced pulmonary inflammation was expected to occur $(5,6)$. In other studies, extra uninfected animals were included to determine 1) the kinetics of clearance of RSHZ19 in serum and lung lavage and 2) whether residual neutralizing antibody in lung lavage fluids could be detected.

Histologic studies. Lungs designated for histologic studies were fixed in Omnifix (Zymed Laboratories, Inc., San Francisco, CA) fixative for a minimum of $24 \mathrm{~h}$, embedded in low melting point paraffin and sectioned at $5 \mu \mathrm{m}$ thickness. Sections were then stained with hematoxylin and eosin, coded, and observed (in a blinded fashion) for perivascular and peribronchial infiltrates, septal thickening, and the presence of inflammatory cells in the alveoli. Ten consecutive microscopic fields on each section were observed using the $40 \times$ objective and an up, over, and down pattern. For each of the four characteristics, a value of 0 to 3 was assigned, with $0=$ not evident; $1=$ evident in 1 to 3 of the fields observed; $2=$ evident in 4 to 6 fields observed, and $3=$ evident in $>6$ of the observed fields. Total scores were obtained by adding scores for each of the four characteristics noted above (the maximum score for an individual animal would be 12).

Statistics. The Newman-Keuls multiple comparison test and Kruskal-Wallis analysis of variance were used to compare geometric mean titers in different groups. Sera with undetectable neutralizing titers or lung fluid samples with undetectable virus titers were assigned a value of 0.5 or 0.8 , respectively, for statistical evaluation. These tests and the determination of all descriptive statistics (i.e. geometric mean titers and SD) were all performed using True Epistat, a statistical program designed by T. L. Gustafson of Epistat Services, Richardson, TX, for IBM-compatible computers. To determine whether RSHZ19 was equipotent against type A versus type B challenge, power calculations based on regression analysis of the dose responses were utilized.

\section{RESULTS}

Antiviral activity of test MAb in vitro. The MAb used in this study were tested for their ability to completely inhibit growth of a panel of different RSV subtype A and B strains in in vitro neutralization antibody assays (Table 1). As indicated by the relatively low $\mathrm{EC}_{50}$ values obtained for RSHZ19 $\left(\mathrm{EC}_{50}\right.$ values ranging from 0.4 to $3 \mu \mathrm{g}$ protein $/ \mathrm{ml}$ ), this MAb had marked, and equivalent, virus-neutralizing activity against all of the RSV strains tested, regardless of their subtype. HSIg also neutralized all RSV strains tested, but $\mathrm{EC}_{50}$ values were significantly higher than those observed with RSHZ19 (12.5-25 $\mu \mathrm{g} / \mathrm{ml}$ versus $0.4-3 \mu \mathrm{g} / \mathrm{ml}$, respectively). In contrast, the control CMHZOO MAb had no significant neutralizing activity against $\mathrm{RSV}$ isolates of either subtype $\left(\mathrm{EC}_{50}\right.$ values were $>114$ $\mu \mathrm{g} / \mathrm{ml})$. The activity of the test MAb in FI assays was equivalent to that observed in the neutralization assays (i.e. the mean $\mathrm{EC}_{50}$ of RSHZ19 against the different RSV stains was $=0.5$ $\mu \mathrm{g} / \mathrm{ml}$, whereas that of the CMHZOO MAb was $>130 \mu \mathrm{g} / \mathrm{ml}$; data not shown). FI titers of HSIg were approximately 5-fold higher than corresponding neutralization titers $(65-130 \mu \mathrm{g} / \mathrm{ml}$; data not shown).

Concentration of RSHZ19 in plasma and lung lavage fluid after intraperitoneal administration. Concentrations of RSHZ19 in plasma and lung lavage fluids from uninfected cotton rats $(n=3)$ at selected time points were determined using the anti-idiotype ELISA (Fig. 1). Within hours of dosing animals with $10 \mathrm{mg} / \mathrm{kg}$ RSHZ19 intraperitoneally, significant concentrations of human antibody were detected in the plasma and in lavage fluids. Maximal concentrations of RSHZ19 occurred in the plasma (approximately $20-40 \mu \mathrm{g} / \mathrm{ml}) 8-72 \mathrm{~h}$ after dosing, and peak lavage concentrations $(0.4-0.7 \mu \mathrm{g} / \mathrm{ml}, 3$ $\mathrm{ml}$ total) were observed $24-72 \mathrm{~h}$ post-dose. At $1 \mathrm{wk}(168 \mathrm{~h})$, the plasma concentrations were about half-maximal, and the lung lavage concentrations of MAb were approximately twothirds of the maximum levels. In general, the amount of

Table 1. Comparison of the in vitro neutralizing activity of RSHZ19 and CMHZOO MAb against different RSV strains and subgroups*

\begin{tabular}{lcccc}
\hline & & \multicolumn{3}{c}{$\mathrm{EC}_{50}(\mu \mathrm{g} / \mathrm{ml})$} \\
\cline { 3 - 5 } RSV strain & Subgroup & $\mathrm{RSHZ19}$ & $\mathrm{CMHZOO}$ & $\mathrm{HSIg}$ \\
\hline 47063 & $\mathrm{~B}$ & $1.5,0.8$ & $>114,>114$ & 12.5 \\
A2 & $\mathrm{A}$ & $0.4,0.8$ & $>114,>114$ & $12.5,25.0$ \\
Long & $\mathrm{A}$ & $1.5,1.5$ & $>114,>114$ & $\mathrm{NT}$ \\
Tracey & $\mathrm{A}$ & $1.5,0.7$ & $>114,>114$ & $\mathrm{NT}$ \\
Cono & $\mathrm{A}$ & $3.0,0.8$ & $>114,>114$ & 12.5 \\
18537 & $\mathrm{~B}$ & $3.0,1.3$ & $>114,>114$ & $12.5,25.0$ \\
Hall & $\mathrm{B}$ & $3.0,0.9$ & $>114,>114$ & 12.5 \\
37335 & $\mathrm{~A}$ & $0.8,0.7$ & $>114,>114$ & 25.0 \\
\hline
\end{tabular}

* Values separated by commas represent results from two separate experiments. NT $=$ not tested. 


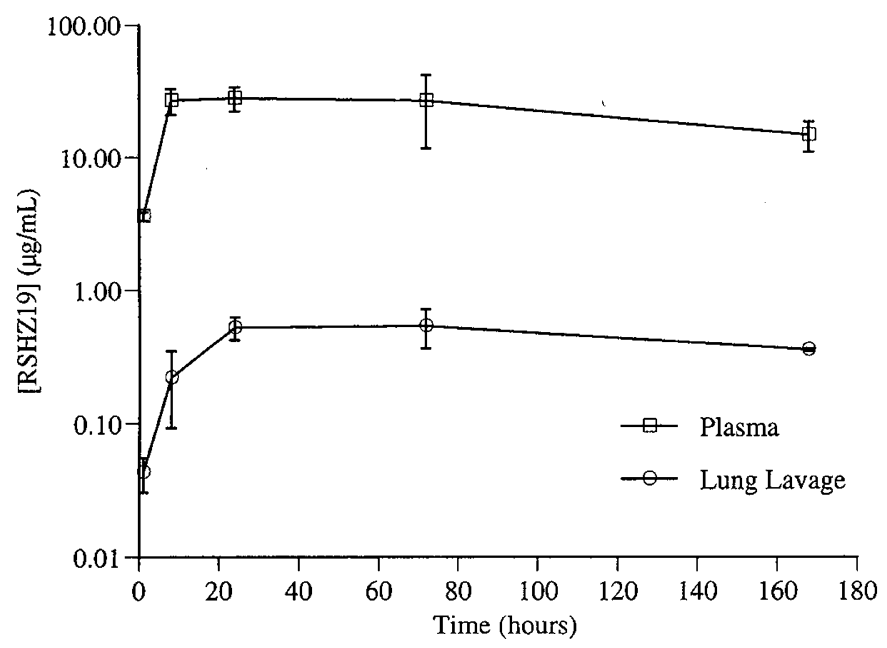

Figure 1. Mean concentrations $\pm \mathrm{SD}(\mu \mathrm{g} / \mathrm{ml})$ of RSHZ19 in plasma $(\square)$ and lung lavage fluids $(O)(0.3-\mathrm{ml}$ initial volume) obtained from uninfected cotton rats ( $n=3$, composite sampling) $1,8,24,72$, and $168 \mathrm{~h}$ after intraperitoneal administration $(10 \mathrm{mg} / \mathrm{kg})$. Mean plasma concentrations $\pm \mathrm{SD}$ were $3.6 \pm 0.25$ $(1 \mathrm{~h}), 27.0 \pm 5.9(8 \mathrm{~h}), 28.7 \pm 5.7(24 \mathrm{~h}) 26.6 \pm 14.9(72 \mathrm{~h})$, and $14.7 \pm 3.8$ $(168 \mathrm{~h})$. Mean lung lavage concentrations $\pm \mathrm{SD}$ were $0.04+0.01(1 \mathrm{~h}), 0.22$ $\pm 0.13(8 \mathrm{~h}), 0.52 \pm 0.10(24 \mathrm{~h}), 0.54 \pm 0.18(72 \mathrm{~h})$, and $0.35 \pm 0.01$ (168 h). An assay background (equivalent to $0.16 \mu \mathrm{g} / \mathrm{ml}$ RSHZ19) was observed in pooled cotton rat plasma from untreated animals and was subtracted from the values shown. No background was observed in pooled lung lavage fluid from untreated cotton rats.

RSHZ19 in the lung lavage was estimated to be $1 \%$ of the amount in plasma. The electrophoretic integrity of the RSHZ19 MAb in lung lavage was confirmed by Western blot analysis (data not shown). Lung lavage and plasma concentration time curves after intramuscular administration were similar up to $168 \mathrm{~h}$ ( $7 \mathrm{~d}$, not shown). These studies thus confirmed that MAb levels remained relatively constant for the duration of virus shedding (i.e. d 1-6 postchallenge).

Pulmonary RSV and serum virus neutralization titers after prophylactic or therapeutic administration of RSHZ19. Mean pulmonary RSV and virus-neutralizing serum titers measured in cotton rats in which RSHZ19 was administered i.p. $24 \mathrm{~h}$ before challenge with subgroup A or B RSV strains are shown in Table 2. The virus titers and serum neutralizing titers were determined on $\mathrm{d} 4$ postchallenge. In all experiments, the reductions in pulmonary virus titers seen were directly proportional to the dose of RSHZ19 MAb administered and to the levels of virus-neutralizing antibody in the serum at the time of sacrifice. At the $10 \mathrm{mg} / \mathrm{kg}$ dose, lung virus was undetectable in both the $\mathrm{A}$ and $\mathrm{B}$ challenge groups, indicating clearance of at least $2.3 \log _{10} / \mathrm{g}$ lung, which corresponded to serum neutralization titers of 1:32. In one prophylaxis study (for which histology results are shown later in Table 4), a parallel group of animals were also sacrificed on $\mathrm{d} 7$ postinfection, and no lung virus was detected in control or RSHZ19-treated animals, indicating the infection had resolved as expected (data not shown).

The mean pulmonary RSV titers and circulating anti RSVneutralizing titers seen in cotton rats given RSHZ19 or control MAb CMHZOO $4 \mathrm{~d}$ after challenge with either subtype A or B $\mathrm{RSV}$ are also shown in Table 2. Animals were killed $24 \mathrm{~h}$ after antibody treatment (i.e. on $\mathrm{d} 5$ postinfection).

Significant reductions in pulmonary RSV titers occurred in groups of cotton rats given $\geq 1 \mathrm{mg} / \mathrm{kg}$ RSHZ19 MAb. Doseresponse curves for animals challenged with either type A or B virus were overlapping, showing that protection versus subgroup A or B strains was equivalent when MAb was administered therapeutically. [Power calculations of the dose re-

Table 2. Comparison of lung virus titers and serum neutralizing activity in type A or B RSV-infected cotton rats treated prophylactically or therapeutically with RSHZ19 MAb

\begin{tabular}{|c|c|c|c|c|c|}
\hline \multirow[b]{2}{*}{$\mathrm{MAb}$} & \multirow{2}{*}{$\begin{array}{c}\text { Dose } \\
(\mathrm{mg} / \mathrm{kg})\end{array}$} & \multirow{2}{*}{$\begin{array}{c}\text { Serum Nt titer } \\
\left(\log _{2}\right) \\
\end{array}$} & \multirow{2}{*}{$\begin{array}{c}\text { Serum concentration } \\
\text { of RSHZ19 MAb } \\
(\mu \mathrm{g} / \mathrm{ml})\end{array}$} & \multicolumn{2}{|c|}{ Lung virus titer $\left(\log _{10} / \mathrm{g}\right)$} \\
\hline & & & & Type A $(n \geq 6)$ & Type B $(n=4)$ \\
\hline \multicolumn{6}{|l|}{ Prophylaxis* } \\
\hline PBS & - & $0.8 \pm 0.6$ & & $4.0 \pm 0.4$ & $3.6 \pm 0.3$ \\
\hline CMHZOO & 10 & $1.1 \pm 0.6$ & ND & $4.1 \pm 0.7$ & $3.9 \pm 0.3$ \\
\hline RSHZ19 & 1.25 & 2.5 & ND & $3.9 \pm 0.3$ & $1.9 \pm 1.0^{* *}$ \\
\hline RSHZ19 & 2.5 & 3.4 & ND & $3.3 \pm 0.6$ & ND \\
\hline RSHZ19 & 5.0 & $4.5 \pm 0.4^{* *}$ & ND & $1.4 \pm 0.8^{* *}$ & $1.0 \pm 0.9^{* *}$ \\
\hline \multirow[t]{2}{*}{ RSHZ19 } & 10.0 & 5.0 & ND & $<1.3^{* *}$ & $<1.3^{* *}$ \\
\hline & & & & Type A $(n=8)$ & Type B $(n=8)$ \\
\hline \multicolumn{6}{|l|}{ Therapy $\ddagger$} \\
\hline CMHZOO & 10 & $1.8 \pm 1.4$ & $<1$ & $3.5 \pm 0.4$ & $3.8 \pm 0.3$ \\
\hline RSHZ19 & 0.3 & $1.7 \pm 1.7$ & $1.3 \pm 0.4$ & $3.6 \pm 0.3$ & $3.5 \pm 0.4$ \\
\hline RSHZ19 & 1.0 & $3.2 \pm 1.1^{* *}$ & $3.3 \pm 0.5$ & $2.6 \pm 0.5^{* *}$ & $2.7 \pm 0.4^{* *}$ \\
\hline RSHZ19 & 3.3 & $4.1 \pm 0.7^{* *}$ & $13.8 \pm 10$ & $2.1 \pm 0.5^{* *}$ & $2.2 \pm 0.8^{* *}$ \\
\hline RSHZ19 & 10.0 & $5.0 \pm .06^{* *}$ & $45.6 \pm 21$ & $1.5 \pm 0.6^{* *}$ & $1.4 \pm 0.8^{* *}$ \\
\hline
\end{tabular}

${ }^{*}$ MAb were administered intraperitoneally $24 \mathrm{~h}$ before challenge with subgroup A or subgroup B RSV strains. Mean serum neutralization (Nt) titer \pm SD and mean lung virus titers $\pm \mathrm{SD}$ were determined $4 \mathrm{~d}$ postchallenge. The total number of animals tested per treatment group and challenged with type $\mathrm{A}$ virus were as follows: PBS $(n=11)$, CMHZOO $(n=7)$, RSHZ19 $1.25 \mathrm{mg} / \mathrm{kg}(n=11), 2.5 \mathrm{mg} / \mathrm{kg}(n=6), 5.0 \mathrm{mg} / \mathrm{kg}(n=9)$, and $10 \mathrm{mg} / \mathrm{kg}(n=8)$. Nt titers were performed in a subset of these experiments and represent the mean \pm SD regardless of challenge with type $A$ or $B$ virus. (ND $=$ not done). Nt titers for animals treated with 10,5 , or $1.25 \mathrm{mg} / \mathrm{kg}$ were obtained in only two experiments $(n=6$ animals total).

¥ Cotton rats were infected with subgroup A or B virus, and treated with MAb on d 4 postinfection. Serum neutralization titers, serum MAb concentrations (determined by anti-idiotype ELISA), and lung virus titers were determined $24 \mathrm{~h}$ later (on $\mathrm{d} 5$ postinfection).

${ }^{* *} p \leq 0.05$ when compared to geometric mean titers in the group treated with control MAb CMHZOO. 
sponse curves indicated that only differences in virus titer $\geq 0.6$ $\log _{10}$ would be statistically significant $(p=0.05)$.] The highest protective dose of RSHZ19 tested $\left(10 \mathrm{mg} / \mathrm{kg}\right.$; $\geq 2.0 \log _{10}$ reduction in virus titer) corresponded to a mean serum neutralization titer of 1:32. An approximate linear correlation between $\mathrm{MAb}$ dose and serum concentration as measured in the antiidiotype ELISA was demonstrated with peak serum MAb concentrations comparable to those in uninfected cotton rats (Table 2 versus Fig 1). Minimum serum levels of approximately $3.3 \mu \mathrm{g} / \mathrm{ml}$ were required for significant lung virus reduction, and maximum virus clearance was observed at mean circulating Mab concentrations of $45.6 \mu \mathrm{g} / \mathrm{ml}$. The serum MAb concentration divided by the corresponding serum neutralizing titer ranged from 0.1 to $1.3 \mu \mathrm{g} / \mathrm{ml}$, indicating that the $\mathrm{MAb}$ activity in serum was comparable to the in vitro activity of the MAb standard $\left(\mathrm{EC}_{50}=0.4-3 \mu \mathrm{g} / \mathrm{ml}\right.$; see Table 1$)$. Significant RSV-neutralizing activity was not detected in lung lavage fluid collected from Mab-treated infected or uninfected cotton rats, even when very low doses of virus $\left(3-10 \mathrm{TCID}_{50}\right.$ ) were used in the neutralization assay.

Effects of passively administered RSHZ19 MAb on RSV nasal titers. Although significant reductions in pulmonary RSV titers were seen in all experiments conducted in cotton rats inoculated intraperitoneally with RSHZ19 MAb, a significant reduction in mean nasal RSV titers compared to control animals (approximately $1 \log _{10}$ ) was observed in only one of three experiments in which nasal titers were determined (data not shown).

Comparison of prophylaxis with RSHZ19 MAb and HSIg. The protective activity of RSHZ19 for prophylaxis was next compared to a conventional intramuscular formulation of HSIg utilizing the same protocol described above, except that both the MAb and HSIg were administered intramuscularly. As the results in Table 3 show, there was approximately 20-30-fold more circulating human IgG (determined by ELISA) in the cotton rats given the high dose $(1000 \mathrm{mg} / \mathrm{kg})$ of HSIg than in the animals given $10 \mathrm{mg} / \mathrm{kg}$ of RSHZ19 MAb $(0.99-1.4 \mathrm{mg} / \mathrm{ml}$ versus $0.05 \mathrm{mg} / \mathrm{ml}$, respectively). Despite the higher levels of circulating human $\operatorname{IgG}$, neutralizing titers in groups administered the high dose of HSIg were equal to (experiment 1 ) or less than (experiment 2) those in the groups that received RSHZ19 MAb, although virus clearance was clearly not as efficient in animals treated with HSIg even when equivalent circulating neutralizing titers were reached. Pulmonary viral clearance below the level of detection was observed in both experiments in cotton rats treated with $10 \mathrm{mg} / \mathrm{kg}$ RSHZ19, whereas the maximal dose of HSIg $(1000 \mathrm{mg} / \mathrm{kg})$ resulted in only moderately reduced virus titer (reduction $=1.2 \log _{10} / \mathrm{g}$ lung in experiment 1) or no significant reduction (in experiment 2, in which this HSIg group did not exhibit a significant RSV serum-neutralizing titer). Thus, for HSIg, RSV lung titer correlated inversely with the serum RSV-neutralizing antibody titer and not with serum human IgG concentrations.

Pulmonary histopathology in cotton rats passively administered $M A b$. Histologic evaluations were made on lungs obtained from cotton rats administered RSHZ19 prophylactically or therapeutically (Table 4). In these experiments, inflammatory cells were occasionally seen around blood vessels (perivascularly), bronchi and bronchioles, and occasionally within alveoli, in sections of lung taken from normal (i.e. non-virus-infected, untreated) cotton rats (Fig. 2A). However, the sections of lung from these animals were generally unremarkable. Indeed, using the scoring system described above, all sections from normal cotton rats had a total score $\leq 1.0$.

In contrast, numerous foci of inflammatory cells were seen on $\mathrm{d} 4$ and 7 postinfection in the perivascular and peribronchiolar regions of the lung, and in the alveoli, in lung sections from virus-infected cotton rats given placebo (PBS), irrelevant MAb (CMHZOO), or $<1 \mathrm{mg} / \mathrm{kg}$ RSHZ19 (Fig. 2, $B$ through $D$, and Table 4). The frequency of these observations was reflected by total histopathology scores for these sections ranging from 8 to 10 .

Intermediate total histopathology scores ranging from 3 to 7 were recorded for cotton rats given $>1$ to $3.3 \mathrm{mg} \mathrm{RSHZ19} / \mathrm{kg}$. Total scores comparable to background values ( 0 to 1 ) occurred in sections of lung from RSV-infected animals given the highest doses $(5-10 \mathrm{mg} / \mathrm{kg})$ of RSHZ19, although virus titrations in parallel groups of animals detected low levels of residual virus (approximately $1 \log _{10}$, see Table 2 ) in these groups. In no instance was there any evidence of exacerbated

Table 3. Comparison of lung virus titers and serum neutralizing activity in cotton rats treated prophylactically with RSHZ19 MAb, control CMHZOO MAb, or HSIg*

\begin{tabular}{|c|c|c|c|c|c|c|}
\hline Expt. & $\mathrm{MAb}$ & $\begin{array}{c}\text { Dose } \\
(\mathrm{mg} / \mathrm{kg})\end{array}$ & $\begin{array}{c}\text { Serum Nt titer } \\
\left(\log _{2}\right) \\
\end{array}$ & $\begin{array}{l}\text { Serum human IgG } \\
(\mathrm{mg} / \mathrm{ml})\end{array}$ & $\begin{array}{l}\text { Lung virus titer } \\
\left(\log _{10} / \mathrm{g}\right)\end{array}$ & $\begin{array}{l}\log _{10} \text { virus } \\
\text { reduction }\end{array}$ \\
\hline \multirow[t]{5}{*}{1} & CMHZOO & 10 & $3.3 \pm 0.4$ & $0.04 \pm 0.10$ & $3.6 \pm 0.3$ & - \\
\hline & RSHZ19 & 10 & $6.3 \pm 0.8^{* *}$ & $0.05 \pm 0.02$ & $<1.3^{* *}$ & $>2.3$ \\
\hline & HSIg & 10 & $2.5 \pm 0.5$ & $0.02 \pm 0.01$ & $2.8 \pm 0.4$ & 0.8 \\
\hline & HSIg & 100 & $3.8 \pm 0.4$ & $0.20 \pm 0.03$ & $3.6 \pm 0.4$ & 0 \\
\hline & HSIg & 1000 & $6.0 \pm 0.7^{* *}$ & $1.40 \pm 0.20$ & $2.4 \pm 0.7^{* *}$ & 1.2 \\
\hline \multirow[t]{5}{*}{2} & CMHZOO & 10 & $2.3 \pm 0.5$ & $0.04 \pm 0.02$ & $3.7 \pm 0.6$ & - \\
\hline & RSHZ19 & 10 & $7.0 \pm 0.8^{* *}$ & $0.05 \pm 0.01$ & $<1.3^{* *}$ & $>2.4$ \\
\hline & HSIg & 10 & $3.5 \pm 0.6$ & $0.42 \pm 0.25$ & $3.7 \pm 0.6$ & 0 \\
\hline & HSIg & 100 & $4.0 \pm 0.8$ & $0.55 \pm 0.08$ & $3.2 \pm 0.3$ & 0.5 \\
\hline & HSIg & 1000 & $4.0 \pm .00$ & $0.99 \pm 0.20$ & $3.1 \pm 0.3$ & 0.6 \\
\hline
\end{tabular}

* MAb or HSIg were administered intramuscularly $24 \mathrm{~h}$ before challenge with subgroup A (strain A2) RSV. Mean serum neutralization (Nt) titers, serum human IgG concentrations by ELISA, and lung virus titers [ $\doteq \mathrm{SD}$ (four animals per experiment)] were determined $4 \mathrm{~d}$ postchallenge.

** $p<0.05$ when compared with the geometric mean titers in the group administered control MAb CMHZOO. 
Table 4. Histologic scores for cotton rats treated prophylactically or therapeutically with RSV-specific RSHZ19, control MAb CMHZOO, or placebo (PBS)

\begin{tabular}{cccc}
\hline \multirow{2}{*}{$\begin{array}{c}\text { MAb } \\
\text { administered }\end{array}$} & $\begin{array}{c}\text { Dose } \\
(\mathrm{mg} / \mathrm{kg})\end{array}$ & \multicolumn{2}{c}{ Dotal histopathology score } \\
\cline { 4 - 5 } Day 4 & Day 7 \\
\hline Prophylaxis* & & $1,1,1$ & $1,1,0$ \\
PBS (-RSV) & - & $10,9,9$ & $10,10,9$ \\
PBS (+RSV) & - & $10,8,9$ & $10,9,9$ \\
CMHZOO & 10 & $10,10,10$ & $11,9,10$ \\
RSHZ19 & 0.63 & $6,6,6$ & $7,7,6$ \\
RSHZ19 & 1.25 & $5,4,6$ & $4,6,7$ \\
RSHZ19 & 2.5 & $1,1,1$ & $1,1,1$ \\
RSHZ19 & 5.0 & & \\
Therapy $\ddagger$ & & ND & $0,1,1$ \\
PBS (-RSV) & - & ND & $10,10,9$ \\
PBS (+RSV) & - & ND & $10,8,9$ \\
CMHZOO & 10 & ND & $10,9,10$ \\
RSHZ19 & 0.3 & ND & $6,5,4$ \\
RSHZ19 & 1.0 & ND & $4,4,3$ \\
RSHZ19 & 3.3 & ND & $0,1,1$ \\
RSHZ19 & 10 &
\end{tabular}

* MAb were administered intraperitoneally $24 \mathrm{~h}$ before challenge with subgroup A RSV strain A2 and lungs were removed on d 4 and 7 for processing. Commas separate scores for individual animals.

$¥$ Cotton rats were infected with subgroup B strain 18537 and were treated with MAb on $\mathrm{d} 3$ postinfection. Lungs were removed on $\mathrm{d} 7$ for processing. Commas separate scores for individual animals. ND $=$ not done.

pulmonary disease in cotton rats administered MAb (i.e. total histopathology scores were never greater for animals given virus and MAb than for virus-infected animals given either PBS placebo or control MAb CMHZOO).

\section{DISCUSSION}

A major aim of these studies was to determine the in vivo efficacy of RSHZ19 MAb against virus strains belonging to both the A and B subgroups of RSV. In in vitro microneutralization assays, RSHZ19 was active against RSV strains belonging to both major subgroups as indicated by the consistently low $\mathrm{EC}_{50}$ values (Table $1 ; 0.4-3 \mu \mathrm{g}$ protein $/ \mathrm{ml}$ ) obtained against a panel of different subtype A and B RSV strains. Moreover, therapeutic administration of a single dose of RSHZ19 MAb $4 \mathrm{~d}$ after virus challenge consistently resulted in significant protection, regardless of whether the challenge virus was a subtype A (e.g. RSV A2;) or B RSV (e.g. 18537) strain. Sufficient numbers of animals were not used to statistically compare protection between RSV subgroups when the MAb was administered prophylactically; however, the results followed the same trend except that virus (subgroup A or B) was reduced to below detectable levels at the highest $\mathrm{MAb}$ dose administered $(10 \mathrm{mg} / \mathrm{kg})$. This consistency allowed assignment of an $\mathrm{EC}_{50}$ in cotton rats against RSV of approximately $3.3 \mathrm{mg}$ of protein $/ \mathrm{kg}$, and confirmed the broad spectrum anti-RSV activity of this reshaped human MAb. Although MAb levels in lung lavage were readily detectable by antiidiotype ELISA, neutralization titers could not be detected. This is consistent with the determined MAb concentrations in lung lavage samples (by ELISA; Fig. 1) being less than or equal to the $\mathrm{MAb} \mathrm{EC}_{50}$ in neutralization assays. Presumably, this represents a dilution effect, and local Mab concentrations were sufficient for effective neutralization as evidenced by reduction in lung virus titers.

A second aim of these studies was to directly compare the protection provided by RSHZ19 with a lot of conventional polyclonal HSIg. Studies by Siber et al. (8) indicated that hyperimmune plasma pools or $\operatorname{IgG}$ fractions $(1 \% \operatorname{IgG})$ with neutralization titers of $1: 1859-1: 3415(3-5 \mu \mathrm{g} / \mathrm{ml})$, as assayed by microneutralization, represented a 5 -fold enrichment over standard i.v. Ig. The neutralization titer of the HSIg used in our experiments was approximately $12.5-25.0 \mu \mathrm{g} / \mathrm{ml} \mathrm{IgG}$, and therefore is similar in titer to standard i.v. Ig preparations as tested by these investigators. As indicated by the data in Table 3 , RSHZ19 was active at markedly lower doses and serum concentrations than standard HSIg when tested in parallel. The reductions seen with the HSIg in the present study were similar to those reported by Prince et al. (6) who showed that intraperitoneal inoculation of $1000 \mathrm{mg} / \mathrm{kg}$ i.v. Ig (RSV-neutralizing titer, 1:2905) reduced pulmonary RSV titers only about $1 \log _{10}$ compared with the control group, despite serum IgG concentrations of $3.7 \mathrm{mg} / \mathrm{ml}$ and serum neutralization titers of 1:59. Notably, prophylactic administration of $500 \mathrm{mg} / \mathrm{kg}$ human immune globulin enriched for neutralizing activity against RSV (RSV Ig) resulted in a 2-log reduction in lung virus titer in cotton rats, demonstrating significantly improved potency relative to conventional HSIg (22). The current studies demonstrate that $10 \mathrm{mg} / \mathrm{kg}$ RSHZ19 administered prophylactically to cotton rats consistently reduced the virus titers to below detectable levels $\left(\geq 2.3 \log _{10}\right.$ reduction), indicating significantly improved potency compared with either conventional HSIg or to RSVIg. Our results also suggest that higher circulating neutralizing titers may be required for complete clearance of lung virus when the Mab is administered therapeutically versus prophylactically, as had also been reported for HSIg in cotton rats (5). Previous studies with HSIg in cotton rats consistently showed more dramatic effects in reduction of lung virus titers versus viral titers in nasal turbinates $(11,22)$, as was the case with RSHZ19 MAb.

The disparity between protective serum RSV neutralizing titers in animals treated with RSHZ19 ( $\geq 1: 32)$ compared with titers of 1:200-1:400 that have been associated with passive protection by polyclonal immune globulins and RSVIg in cotton rats or in infants $(8,10,11,22)$, may be due to the homogeneity of the RSHZ19 MAb, compared with the heterogeneity of the HSIg preparation where only a subset of the neutralizing antibodies present may actually be protective. For example, an analysis of F protein-specific MAb indicated that FI activity is the most reliable indicator of in vivo protection (15), although only a subset of those MAb that are neutralizing also have fusion-inhibiting activity $(15,23)$. Thus, in addition to reduced antiviral potency based on a comparison of neutralization titers (approximately 12-25-fold) or fusion inhibition titers (approximately 65-130-fold), the ratio of neutralizing to fusion-inhibiting activity of the RSHZ19 MAb versus the lot of HSIg used in the current study (1.0 versus 5.0 , respectively) may also contribute to the relative difference in potency observed. 


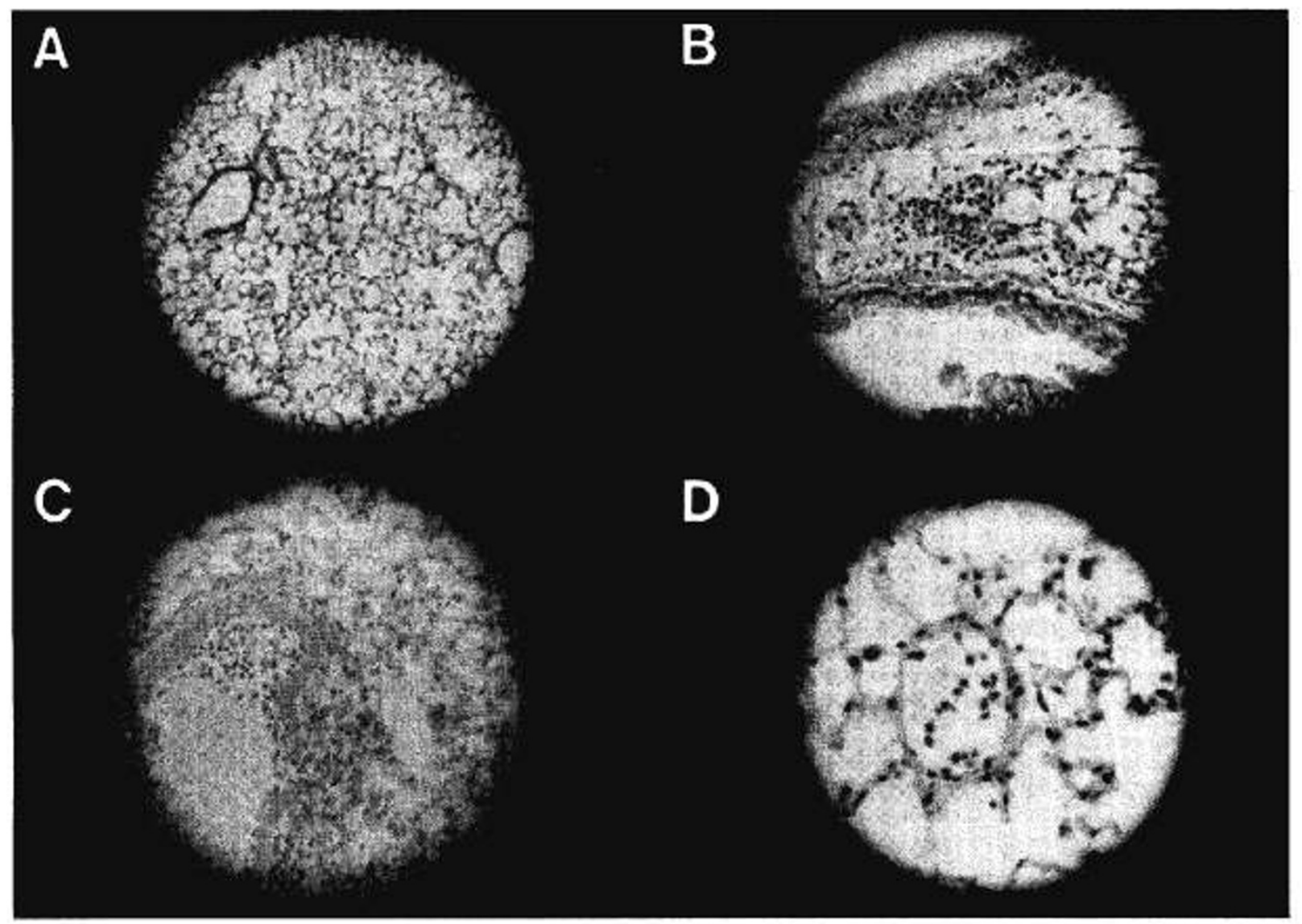

Figure 2. Typical histopathology seen in lungs of cotton rats infected with RSV. (A) Photomicrograph of a section of lung from an uninfected cotton rat stained with hematoxylin and eosin $(\times 230)$. (B-D) Photomicrographs (all $\times 920)$ showing similarly stained sections taken $96 \mathrm{~h}$ after RSV inoculation. $B$ provides an example of peribronchiolar infiltration, $C$ an example of perivascular infiltration, and $D$ an example of inflammatory cells in alveoli.

Exacerbation of RSV disease has been associated with attempts to induce active immunity to RSV, but not passive immunity in studies utilizing polyclonal $\lg (5)$ (reviewed in Ref. 11). However, because RSHZ19 is directed to a single F protein epitope, the capacity of this MAb to induce pulmonary histopathology could not be predicted based on previous studies. For this reason, a determined effort was made to compare the pulmonary histopathology seen in MAb-treated, RSVinfected animals with that seen in virus-infected, untreated control animals. The results obtained clearly show that the pulmonary histopathology correlated directly with pulmonary virus titers and inversely with both the amount of RSHZ19 MAb administered and the levels of serum anti-RSV titers reached. Under the conditions of the experiments performed, enhanced histopathology did not occur in lungs of any of the cotton rats. It is important to note that only limited time points (d 4 and 7 postinfection) were utilized in these experiments. However, we (24) and others (25), have induced increased and severe pulmonary immunopathology (i.e. exacerbated disease) in the same timeframe in cotton rats as was studied here by giving formalin-inactivated RSV vaccines prior to intranasal challenge with RSV. Although these results in cotton rats and initial safety studies in normal adults are encouraging (16), studies in pediatric patients infected with RSV will ultimately be required to determine the safety profile of RSHZ19.

In summary, the protection seen in these studies in cotton rats treated with the RSHZ19 MAb was rapid and often impressive [reductions of pulmonary virus to below detectable levels with the use of modest amounts of antibody (5-10 $\mathrm{mg} / \mathrm{kg}$ )] with no evidence of enhanced disease. The data obtained thus support further clinical development of the RSHZ19 MAb for prophylaxis and therapy of RSV lower respiratory disease in infants and young children.

Acknowledgments. The authors thank Dr. Martin Rosenberg of SmithKline Beecham Pharmaceuticals and Drs. William Harris and Frank Carr of Scotgen Biopharmaceuticals for expert advice and for reviewing this manuscript, and C. J. Howard and B. Jones for help in preparation of the antiidiotypic MAb.

\section{REFERENCES}

1. Channock RM, McIntosh K 1990 Parainfluenza viruses. In: Fields BN (ed) Virology. Raven Press, New York, pp 963-988

2. Committee on Infectious Diseases 1993 Use of ribavirin in the treatment of respiratory syncytial virus in infection. Pediatrics 92:501-504

3. Bradley JS, Conner JD, Campogiannis LM 1990 Exposure of health care workers to ribavirin during therapy for respiratory syncytial virus infection. Antimicrob Agents Chemother 34:68-70

4. Hemming VG, Prince GA, Horswood RL, London WT, Murphy BR, Walsh EE, Fischer GW, Weisman LE, Baron PA, Channock RM 1985 Studies of passive immunotherapy for infections of respiratory syncytial virus in the respiratory tract of a primate model. J Infect Dis 52:1083-1086

5. Prince GA, Hemming VG, Horswood RL, Channock RM 1985 Immunoprophylaxis and immunotherapy of respiratory syncytial virus infection in the cotton rat. Virus Res 3:193-206

6. Prince GA, Hemming VG, Horswood RL, Baron PA, Channock RM 1987 Effectiveness of topically administered neutralizing antibodies in experimental immunotherapy of respiratory syncytial virus infection in cotton rats. J Virol 61:1851-1854 
7. Graham BS, Davis TH, Tang Y-W, Gruber WC 1993 Immunoprophylaxis and immunotherapy of respiratory syncytial virus-infected mice with respiratory syncytial virus-specific immune serum. Pediatric Res 34:167-172

8. Siber GR, Leszczynski J, Pena-Cruz, Ferren-Gardner C, Anderson R, Hemming VG Walsh EE, Burns J, McIntosh K, Gonin R, Anderson LJ 1992 Protective activity of a human respiratory syncytial virus immune globulin prepared from donors screened by microneutralization assay. J Infect Dis 165:456-463

9. Hemming VG, Rodriquez W, Kim KW, Brandt CD, Parrott RH, Burch B, Prince GA Baron PA, Fink RJ, Reaman G 1987 Intravenous immunoglobulin treatment of respiratory syncytial virus infections in infants and young children. Antimicrob Agents Chemother 31:1882-1886

10. Groothuis JR, Simoes EAF, Levin MJ, Hall CB, Long CE, Rodriquez WJ, Arrobio J, Meissner HC, Fulton DR, Welliver RC, Tristram DA, Siber GR, Prince GA, VanRaden M, Hemming VG 1993 Prophylactic administration of respiratory syncytial virus immune globulin to high-risk infants and young children. $\mathrm{N}$ Engl $\mathrm{J}$ Med 329:1524-1530

11. Hemming VG, Prince GA 1992 Respiratory syncytial virus: babies and antibodies. In: Infectious Agents and Diseases. Raven Press, New York, pp 24-32

12. Billetta R and Lobuglio, AF 1993 Chimeric antibodies. Int Rev Immunol 10:165-176

13. Riechmann $L$, Clark M, Waldmann H, Winter G 1988 Reshaping human antibodies for therapy. Nature 332:323-327

14. Tempest PR, Brenner P, Lambert M, Taylor G, Furze JM, Car FJ, Harris WJ 1991 Reshaping a human monoclonal antibody to inhibit human respiratory syncytial virus infection in vivo. Biotechnology 9:266-271

15. Taylor G, Stott EJ, Furze J, Ford J, Sopp P 1992 Protective epitopes on the fusion protein of respiratory syncytial virus recognized by murine and bovine monoclonal antibodies. J Gen Virol 73:2217-2223

16. Everitt D, Thompson E, DiCicco R, Davis C, Demuth S, Herzyk DJ, Ilson B, Jorkasky D 1995 Safety, pharmacokinetics, antigenicity and fusion inhibition activity of SB 209763, a reshaped human monoclonal antibody to respiratory syncyticial virus. Pediatr Res 37:173A(abstr)
17. Arbiza J, Taylor G, Lopez JA, Furze J, Wyld S, Whyte P, Stott EJ, Wertz G, Sullender W, Trudel M, Melero J 1992 Characterization of two antigenic sites recognized by neutralizing monoclonal antibodies directed against the fusion glycoprotein of human respiratory syncytial virus. J Gen Virol 73:2225-2234

18. Rhodes AJ, vanRooyen CE 1953 Textbook on Virology, 2nd Ed. Williams \& Wilkins, Baltimore, pp 66-69

19. Glezen WP, Paredes A, Allison JE, Taber LH, Frank AL 1981 Risk of respiratory syncytial virus infection for infants from low-income families in relationship to age, sex, ethnic group and maternal antibody level. J Pediatr 98:708-715

20. Mufson MA, Orvell C, Rafnar B, Norrby E 1985 Two distinct types of human respiratory syncytial virus. J Gen Virol 66:2111-2124

21. Wyde PR, Six HR, Wilson. SZ, Gilbert BE, Knight V 1988 Activity against rhinoviruses, toxicity and delivery in aerosol of enviroxime in liposomes. Antimicrob Agents Chemother 32:890-895

22. Siber GR, Leombruno D, Leszczynski J, McIver J, Bodkin D, Gonin R, Thompson C Walsh E, Piedra P, Hemming, VG, Prince GA 1994 Comparison of antibody concentrations and protective activity of respiratory syncytial virus immune globulin and conventional immune globulin. J Infect Dis 169:1368-1373

23. Beeler JA, Van Wyke Coehlingh K 1989 Neutralization epitopes of the F glycoprotein of respiratory syncytial virus: effect of mutation upon fusion function. J Virol 63:2941-2950

24. Piedra PA, Wyde PR, Castleman WL, Ambrose MW, Jewell AM, Speilman DJ, Hildreth SW 1994 Enhanced pulmonary pathology associated with the use of formalin-inactivated respiratory syncytial virus vaccine in cotton rats is not a unique viral phenomenon. Vaccine 11:415-423

25. Prince GA, Jenson AB, Hemming VG, Murphy BR, Walsh EE, Horswood RL, Channock RM 1986 Enhancement of respiratory syncytial virus pulmonary pathology in cotton rats by prior intramuscular inoculation of formalin-inactivated virus. J Virol $57: 721-728$ 